\title{
An impact of municipal sewage sludge and wheaten straw on some indica- tors of soil fertility
}

\author{
Czesław Wołoszyk, Krzysztof Balcer \\ University of Agriculture, Department of Environmental Chemistry, ul. J. Stowackiego 17, 71-434 Szczecin, Poland, \\ woloszyk@agro.ar.szczecin.pl, e-mail:woloszyk@agro.ar.szczecin.pl
}

\begin{abstract}
In a two-factor pot experiment the impact of applied diverse doses of municipal sewage sludge and equal dose of wheaten straw, with and without supplemental mineral N and NPK fertilization, on some fertility properties of soil was assessed. The soil used in the experiment was acid brown incomplete soil (good rye complex). The grass - Festulolium - was the test plant, harvested four times and in the second year - common sunflower and blue phacelia. After the harvest of phacelia, the $\mathrm{pH}$ (in $1 \mathrm{M} \mathrm{KCl}$ ), the content of total nitrogen, total carbon and the available forms of $\mathrm{P}, \mathrm{K}$ and $\mathrm{Mg}$ were analyzed.

Fertilization with sewage sludge and straw failed to have a significant influence on the change of the soil $\mathrm{pH}$. However, all doses of sewage sludge + straw, in comparison with the control, significantly increased the content of total carbon (from 31.8 to $37.8 \%$ ) and total nitrogen (from 34.3 to $52.2 \%$ ) in the soil. There was significantly more phosphorus available in the soil from all the objects with sewage sludge and straw than in the soil from the control object (from 8.2 to $21.6 \%$ ), while the content of potassium was higher only in the soil from the object with $1.5 \%$ of sewage sludge + straw and magnesium at the highest dose of sewage sludge. The mineral N and NPK fertilization, used against the background of sewage sludge and straw, did not have asignificant impact on the shaping of the analyzed soil fertility indicators.
\end{abstract}

Keywords: municipal sewage sludge, wheaten straw, soil, total carbon, total nitrogen, phosphorus, potassium, available magnesium.

Presented at VII Conference Wasteless Technologies and Waste Management in Chemical Industry and Agriculture, Międzyzdroje, 12 - 15 June, 2007.

\section{INTRODUCTION}

A decline of production and the usage of natural fertilizers and a simultaneous increase of cereal participation in the structure of crops is causing a decrease of soil fertility, which is manifested, first and foremost, in the loss and degradation of the soil organic matter. As a result of the above-mentioned situation the necessity of searching for alternative sources of organic matter occurs. The municipal sewage sludge and cereal straw can act as those alternative sources of organic matter. Intensive research confirms the usefulness of both sewage sludge ${ }^{1-3}$ and cereal straw $^{4-5}$. In the case of agricultural utilization of sewage sludge it is recommended to compost it with an addition of materials rich in organic matter (e.g. with straw, sawdust, bark). However, the composting process, conventional or industrial, requires quite considerable financial expenses, which became the premise to take up the research on the assessment of the total application of sewage sludge and wheaten straw with the supplemental mineral N and NPK fertilization, in shaping some of the soil fertility indicators.

\section{MATERIALS AND METHODS}

Over the years 2004 - 2005 the pot experiment was conducted under the foil roof in the hall of vegetation of The University of Agriculture in Szczecin. The soil used in the experiment was taken from the Ap level of arable field of the Experimental Agriculture Station in Lipnik. This soil is numbered among the acid brown as incomplete of a granulometric composition of light very fine sand with $12 \%$ of slit and clay (good rye complex). The $\mathrm{pH}$ reaction before setting up the experiment was acid
$(\mathrm{pH}$ in $1 \mathrm{M} \mathrm{KCl}-5.31)$, the content of the total carbon was $6.03 \mathrm{~g} \cdot \mathrm{kg}^{-1}$, the total nitrogen $0.60 \mathrm{~g} \cdot \mathrm{kg}^{-1}$, the content of available phosphorus was high, potassium medium and magnesium was low.

The scheme of the experiment included two factors, the first was presented by 5 variants: the control and 4 doses of municipal sewage sludge with an addition of wheaten straw at an equal rate, the second factor was a variant without mineral fertilization (0), with mineral nitrogen fertilization (N) and NPK. The doses of municipal sewage sludge, which came from the mechanical-biological sewage treatment in Stargard Szczeciński, were: 0.5, 1.0, 1.5 and $2.0 \%$ of dry matter in relation to $6.0 \mathrm{~kg} \mathrm{d.m}$. of the soil in the pot. Wheaten straw, cut in chaff, was applied in the dose of $30 \mathrm{~g} \mathrm{d.m}$. per pot. Table 1 shows the chemical composition of sewage sludge and straw.

On the objects with Festulolium, fertilized only with mineral nitrogen and NPK, the dose of nitrogen was $1 \mathrm{~g}$ $\mathrm{N}$ per pot (urea $-46 \% \mathrm{~N}$ ). Phosphorus (double superphosphate $-20 \% \mathrm{P}$ ) on the objects with NPK was applied in the amount of $0.164 \mathrm{~g} \mathrm{P}$ and potassium (potash salt $50 \% \mathrm{~K}) 0.312 \mathrm{~g} \mathrm{~K}$ per pot. The test plant was - intergenus hybrid - Festulolium (var. Felopa), which was sown 28.04.2004, and harvested at the following time: I - 18.06., II - 19.07., III - 25.08., IV - 28.09.2004. Throughout all this vegetation period the grass was watered with distilled water, keeping the soil humidity on the $60 \%$ level of full water capacity. After the fourth cut of Festulolium, the soil in the pots was mixed and the stubble mulch was covered, the pots prepared in such a way were stored until spring 2005.

In the second year of research (2005), after loosening the soil in the pots, mineral fertilization was applied. On 
Table 1. The chemical composition of municipal sewage sludge and wheaten straw

\begin{tabular}{|c|c|c|c|c|c|c|c|c|}
\hline \multirow{2}{*}{ Detailed list } & \multirow{2}{*}{$\begin{array}{l}\text { Dry matter } \\
{\left[\mathrm{g} \cdot \mathrm{kg}^{-1} \mathrm{f} . \mathrm{m} .\right]}\end{array}$} & \multirow{2}{*}{$\begin{array}{c}\mathrm{pH} \\
\text { in } \mathrm{H}_{2} \mathrm{O}\end{array}$} & \multicolumn{6}{|c|}{ Total content $\left[\mathrm{g} \cdot \mathrm{kg}^{-1} \mathrm{~d} . \mathrm{m}.\right]$} \\
\hline & & & $C$ & $\mathrm{~N}$ & $\mathrm{P}$ & $\mathrm{K}$ & $\mathrm{Ca}$ & $\mathrm{Mg}$ \\
\hline Sewage sludge & 175 & 7.25 & 372 & 65.6 & 21.6 & 5.01 & 19.2 & 4.60 \\
\hline Wheaten straw & 900 & - & 421 & 4.90 & 1.10 & 13.2 & 2.50 & 1.20 \\
\hline
\end{tabular}

the objects with the N and NPK the dose of nitrogen was $0.50 \mathrm{~g} \mathrm{~N}$, phosphorus on the objects with NPK - $0.164 \mathrm{~g}$ $\mathrm{P}$ and $0.208 \mathrm{~g} \mathrm{~K}$ per pot. Common sunflower, which was harvested after 45 days of vegetation, acted as the test plant and then blue phacelia was sown. On the objects with $\mathrm{N}$ and NPK fertilization, during the time of the vegetation of phacelia, $0.25 \mathrm{~g} \mathrm{~N}$ per pot was applied. After the harvest of phacelia, from three repetitions of each fertilizing object, samples of soil were taken. In the mean object the samples' $\mathrm{pH}$ was analyzed $(\mathrm{pH}$ in $1 \mathrm{M} \mathrm{KCl})$, the content of total nitrogen and carbon was analyzed on the Costech CNS elemental analyzer, the available P and $\mathrm{K}$ were analyzed with the Egner-Riehm method and magnesium with the Schachtschabel method.

\section{RESULTS AND DISCUSSION}

Municipal sewage sludge, used in the experiment, was characterized by a high content of nitrogen, phosphorus and total calcium, while the content of potassium was low (Table 1). However, the content of heavy metals, limited in agriculture utilization of sewage sludge, was lower than the norms included in The Decree of Minister of Environment of 01.08.2002 ${ }^{6}$. The doses of sewage sludge, taken into consideration in the scheme of research, were high because in conversion to the mass of soil from 1 ha amounted to: $15,30,45$ and $60 \mathrm{t}$ d.m. of sewage sludge per ha. The dose of wheaten straw ( $15 \mathrm{t}$ d.m. per ha) was also higher than when used in agriculture practice.

Application of high doses of sewage sludge and straw was a result of expectations of significant differences as a result of the rising doses of sewage sludge on soil properties.

After two years of research significant alkalization of soil was noticed on all the objects of the experiment (Table $2)$, in comparison with the initial state $(\mathrm{pH}=5.31)$.

Table 2. Potential of hydrogen $(\mathrm{pH}$ in $1 \mathrm{M} \mathrm{KCl})$

\begin{tabular}{|l|c|c|c|c|}
\hline Object & 0 & $\mathrm{~N}$ & NPK & Mean \\
\hline Control & 6.15 & 6.30 & 6.35 & 6.26 \\
\hline $\begin{array}{l}\text { Sludge 0,5\% } \\
\text { + straw }\end{array}$ & 6.02 & 6.48 & 6.88 & 6.33 \\
\hline $\begin{array}{l}\text { Sludge 1,0\% } \\
\text { + straw }\end{array}$ & 6.24 & 6.53 & 6.75 & 6.46 \\
\hline $\begin{array}{l}\text { Sludge 1,5\% } \\
\text { + straw }\end{array}$ & 6.45 & 6.52 & 6.62 & 6.52 \\
\hline $\begin{array}{l}\text { Sludge 2,0\% } \\
\text { + straw }\end{array}$ & 6.29 & 6.60 & 6.74 & 6.50 \\
\hline Mean & 6.21 & 6.47 & 6.63 & 6.40 \\
\hline
\end{tabular}

An average increase of the soil $\mathrm{pH}$ from the control object amounted to 0.95 of a unit, on the objects with sewage sludge and straw it was somewhat higher and varied from 1.02 to 1.21 of the unit. Not large differences between the average value of the soil $\mathrm{pH}$ from the control object and the values from the objects with sewage sludge and straw show that organic fertilization did not cause significant changes in $\mathrm{pH}$, rather it had an impact on its stabilization. Jakubus ${ }^{7}$, in her research, after annual application of 2 and $8 \mathrm{t} \cdot \mathrm{ha}^{-1} \mathrm{~d}$.m. of sewage sludge during the period of five years, did not notice any significant changes in the soil pH. However, Baran et al. ${ }^{8}$, in the second year after the application of high doses of sewage sludge (from $1 \%$ to $40 \%$ d.m. of sewage sludge in relation to the soil mass) for the fertilization of very light sand, obtained the increase of the soil $\mathrm{pH}$ by 0.7 of the unit already with $1 \%$ dose of sewage sludge and with higher doses above 1.0 of unit. A small impact of sewage sludge fertilization on the changes in the soil $\mathrm{pH}$, in this research, could be a result of the acidifying effect of straw, because the products of decomposition of straw in the soil have an acid character?.

One of the most important indicators of soil fertility is the content of total or organic carbon. In this research, for the reason of the used method of dry mineralization of the soil, the content of total carbon is presented. In the second year of the research the content of total carbon in the soil from all the objects fertilized with sewage sludge and straw was significantly higher than in the soil from the control object (Table 3).

An average increase of the content of total carbon in the soil under the influence of organic fertilization varied from 31.8 to $37.8 \%$. In spite of large differences of sewage sludge doses, there were no significant differences between individual doses. A similar content of the total carbon in the soil from the objects with higher doses of sewage sludge + straw, like in the soil with lower doses, shows that its content is decreasing faster with the higher doses of sewage sludge. This dependence is confirmed by the results of the research conducted by Korbulewsky et al. ${ }^{10}$, along with rising the doses of the compost prepared from sewage sludge. This faster decomposition of a larger mass of organic matter in the soil Perucci1 ${ }^{\mathbf{1 1}}$ explains with the increase of the biomass and the activity of microorganisms in the soil, which accelerates its mineralization in several months after application.

Municipal sewage sludge is usually rich in nitrogen, which favours enlargement of its content in the soil. However, a significant increase of the content of this nutrient in the soil was obtained after an application of doses higher than $10 \mathrm{t} \cdot \mathrm{ha}^{-1} \mathrm{~d}$.m. of the sewage sludge ${ }^{\mathbf{1 2}}$. In this research, where the doses of sewage sludge amounted from 15 to $60 \mathrm{t} \cdot \mathrm{ha}^{-1} \mathrm{~d} . \mathrm{m}$. and $30 \mathrm{t} \cdot \mathrm{ha}^{-1} \mathrm{~d} . \mathrm{m}$. of the straw, a significant increase of the content of total nitrogen in the soil was obtained, in comparison with the control object (Table 3). An average increase of content of this nutrient in the soil varied from 34.4 to $52.2 \%$. Along with the rising doses of sewage sludge, the content of total nitrogen in the soil was increasing, but the differences between individual doses, like in the case of total carbon, were insignificant.

Analyzing the impact of mineral fertilization on the shaping of the content of total carbon and nitrogen, more of those nutrients were stated in the soil from the objects fertilized with N and NPK than in the objects with exclusive sewage sludge and straw fertilizing, but the differences were not statistically confirmed. 
Table 3. The content of the total carbon and nitrogen in the soil $\left(\mathrm{g}^{\mathrm{kg}} \mathrm{kg}^{-1}\right)$

\begin{tabular}{|c|c|c|c|c|c|c|c|c|}
\hline \multirow{2}{*}{ Object } & \multicolumn{4}{|c|}{ Total C } & \multicolumn{4}{|c|}{ Total N } \\
\hline & 0 & $\mathrm{~N}$ & NPK & Mean & 0 & $\mathrm{~N}$ & NPK & Mean \\
\hline Control & 6.27 & 7.70 & 7.54 & 7.17 & 0.61 & 0.71 & 0.70 & 0.67 \\
\hline Sludge $0,5 \%+$ straw & 8.65 & 10.10 & 10.08 & 9.61 & 0.83 & 0.92 & 0.96 & 0.90 \\
\hline Sludge $1,0 \%+$ straw & 9.40 & 9.68 & 9.26 & 9.45 & 0.88 & 0.97 & 0.93 & 0.93 \\
\hline Sludge $1,5 \%+$ straw & 10.67 & 9.03 & 9.94 & 9.88 & 1.10 & 0.89 & 0.99 & 0.99 \\
\hline Sludge $2,0 \%+$ straw & 9.21 & 9.50 & 10.22 & 9.64 & 0.94 & 1.00 & 1.11 & 1.02 \\
\hline Mean & 8.84 & 9.20 & 9.41 & 9.15 & 0.87 & 0.90 & 0.94 & 0.90 \\
\hline$-\mathrm{SD}_{0,05}$ for: - sewage sl & & & & 2.137 & & & & 0.226 \\
\hline
\end{tabular}

Table 4. The value of the C:N ratio in the soil

\begin{tabular}{|l|r|r|r|c|}
\hline Object & 0 & $\mathrm{~N}$ & NPK & Mean \\
\hline Control & 10.28 & 10.84 & 10.77 & 10.63 \\
\hline $\begin{array}{l}\text { Sludge 0,5\% } \\
\text { + straw }\end{array}$ & 10.42 & 10.98 & 10.50 & 10.63 \\
\hline $\begin{array}{l}\text { Sludge 1,0\% } \\
\text { + straw }\end{array}$ & 10.68 & 9.98 & 9.96 & 10.21 \\
\hline $\begin{array}{l}\text { Sludge 1,5\% } \\
\text { + straw }\end{array}$ & 9.70 & 10.15 & 10.04 & 9.96 \\
\hline $\begin{array}{l}\text { Sludge 2,0\% } \\
\text { + straw }\end{array}$ & 9.80 & 9.50 & 9.21 & 9.50 \\
\hline Mean & 10.18 & 10.29 & 10.10 & 10.19 \\
\hline
\end{tabular}

An average value of the $\mathrm{C}: \mathrm{N}$ ratio in the soil from the objects with lower doses of sewage sludge (0.5 and $1.0 \%)$ was similar to its value from the control object (Table 4).

However, in the soil from the objects with 1.5 and $2.0 \%$ of sewage sludge the $\mathrm{C}: \mathrm{N}$ ratio was narrower, which was connected with a higher increase of the content of total nitrogen and carbon. Such relationship shows that organic matter from sewage sludge and straw is mineralized in the soil at a faster pace.

The high content of total phosphorus in municipal sewage sludge does not always cause a significant increase of the content of available forms of this nutrient in the soil. Czekała $^{\mathbf{1 3}}$ is looking for the reason of that situation in the high content of calcium in sewage sludge, which has impact not only on the high value of the sewage sludge $\mathrm{pH}$, but also on the possibility of a creating hardly soluble

combination of phosphorus. The results obtained by us show that all of the sewage sludge doses significantly increase the content of available phosphorus in the soil, in relation to the control (Table 5).

An average increase of the content varied from 8.2 to $21.6 \%$ and in most cases the higher dose of sewage sludge responded to a significant increase of the content of available phosphorus in the soil.

Fertilization with sewage sludge and straw, in comparison with the control object, had also an impact on the increase of the content of available potassium in the soil, but the statistically confirmed increase was obtained only on the object with $1.5 \%$ of sewage sludge + straw and amounted to $12.6 \%$.

From the fertilizing point of view the content of magnesium, which is a deficit nutrient in our soils, is a favour- able property of sewage sludge. However, significant enrichment in available magnesium of the soil fertilized with sewage sludge follows after application of its high doses ${ }^{\mathbf{1 3}}$. The presented research, in which in comparison with the control, the highest dose of sewage sludge had a significant increase on the content of available magnesium, is the confirmation of the above-mentioned dependences (Table 6). An average increase of the content of magnesium in the soil from that object amounted to $24.7 \%$.

On the basis of the conducted research it can be stated that high doses of sewage sludge $\left(30,45,60 \mathrm{t} \cdot \mathrm{ha}^{-1} \mathrm{~d} . \mathrm{m}.\right)$, in comparison with the lowest dose $\left(15 \mathrm{t} \cdot \mathrm{ha}^{-1} \mathrm{~d}\right.$.m. $)$, did not significantly improve the soil fertility indicators $(\mathrm{pH}$, the content of total carbon and nitrogen).

Above-mentioned observations show that for the purpose of maintaining of soil fertility, it is recommended to apply lower doses of organic fertilizers but with higher frequency.

\section{CONCLUSIONS}

1. After the two years of an application of sewage sludge and wheaten straw and annual mineral fertilization, a significant diversity of some analyzed soil fertility indicators were noticed, in comparison with the control object.

2. Fertilization with sewage sludge and straw did not have a significant influence on the change of the soil $\mathrm{pH}$, it rather had stabilized the soil $\mathrm{pH}$.

3. All the doses of sewage sludge + straw, in comparison with the control, significantly increased the content of total carbon (from 31.8 to $37.8 \%$ ) and total nitrogen (from 34.3 to $52.2 \%$ ) in the soil. The increase of the content of total carbon and total nitrogen in the soil between the rising in turn doses of sewage sludge + straw were not significantly different, which shows that faster mineralization of organic matter at high doses of fertilizers and losses of these components from the soil took place.

4. There was significantly more phosphorus available in the soil from all the objects with sewage sludge and straw than in the soil from the control object (from 8.2 to $21.6 \%$ ), while the content of potassium was higher only in

Table 5. The content of available phosphorus and potassium in the soil $\left(\mathrm{mg} \cdot \mathrm{kg}^{-1}\right)$

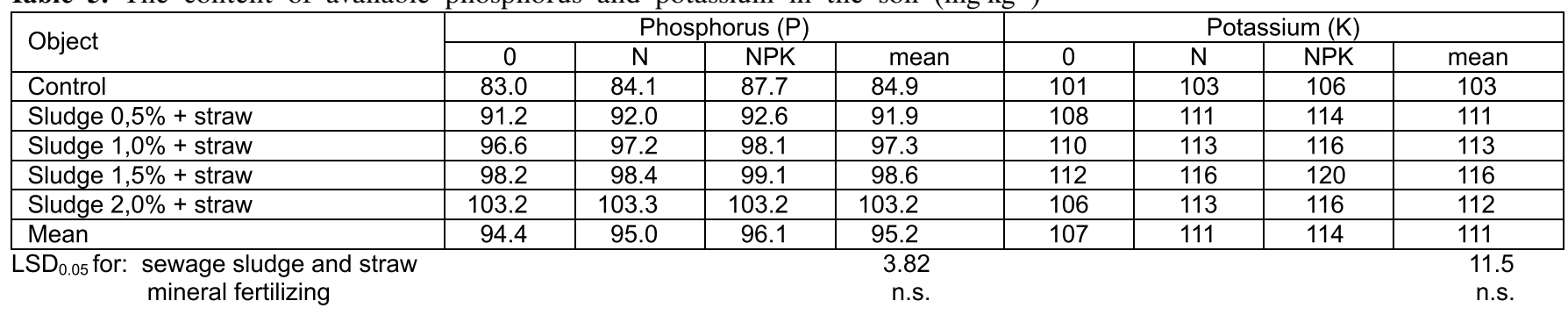


Table 6. The content of available magnesium in the soil $\left(\mathrm{mg} \cdot \mathrm{kg}^{-1}\right)$

\begin{tabular}{|l|c|c|c|c|}
\hline Object & 0 & N & NPK & Mean \\
\hline Control & 24.3 & 24.6 & 22.3 & 23.7 \\
\hline Sludge 0.5\% + straw & 26.6 & 26.1 & 20.6 & 24.4 \\
\hline Sludge 1.0\% + straw & 25.3 & 25.6 & 25.8 & 25.6 \\
\hline Sludge 1.5\% + straw & 25.2 & 25.4 & 25.6 & 25.4 \\
\hline Sludge 2.0\% + straw & 29.0 & 29.6 & 29.9 & 29.5 \\
\hline Mean fow & 26.1 & 26.3 & 24.8 & 25.7 \\
\hline
\end{tabular}

the soil from the object with $1.5 \%$ of sewage sludge + straw and magnesium at the highest dose of sewage sludge.

5. Mineral N and NPK fertilization, used against a background of sewage sludge and straw, did not have a significant impact on the shaping of the analyzed soil fertility indicators.

\section{LITERATURE CITED}

(1) Mazur T:: Rozważania o wartości nawozowej osadów ściekowych. Zesz. Probl. Post. Nauk Rol., 1996, 437, 13 - 22.

(2) Czekała J.: Wybrane właściwości osadów ściekowych z oczyszczalni regionu Wielkopolski. Cz. I. Odczyn, sucha masa, materia i węgiel organiczny oraz makroskładniki, Acta Agrophysica, 2002, 70(I), $75-82$.

(3) Krzywy E., Wołoszyk Cz., Iżewska A.: Wartość nawozowa kompostów z komunalnych osadów ściekowych. Diagnostyka gleb i roślin w rolnictwie zrównoważonym. Monografie 54. Wydaw. AP, Siedlce, 2004, 98 - 109.

(4) Wiater J.: Oddziaływanie nawożenia organicznego na występowanie związków węgla i azotu w glebie pod monokulturą pszenicy ozimej i jęczmienia jarego, Rozpr. AR Lublin, 1997, 201, 77.

(5) Janowiak J., Spychaj-Fabisiak E.: Próchnicotwórcza rola słomy przyorywanej bez obornika i razem $\mathrm{z}$ obornikiem na tle zróżnicowanego nawożenia azotem na glebie lekkiej, Zesz. Probl. Post. Nauk Rol., 2006, 512, 201 - 207.

(6) Rozporządzenie Ministra Środowiska z dnia 1 sierpnia 2002 r. Dziennik Ustaw z dnia 27 sierpnia 2002 r. nr 134 poz. 1140.

(7) Jakubus M.: Wpływ wieloletniego stosowania osadu ściekowego na zmiany wybranych właściwości chemicznych gleby, Zesz. Probl. Post. Nauk Rol., 2006, 512, 209 - 219.

(8) Baran S., Flis-Bujak M., Turski R., Żukowska G.: Zmiany właściwości fizykochemicznych gleby lekkiej użyźnianej osadem ściekowym, Rocz. Glebozn., 2004, 47(3/4), 123 - 130.

(9) Nowak G.: Oddziaływanie słomy na plonowanie roślin i właściwości gleby w czteroletnim doświadczeniu wazonowym, Zesz Nauk. ART. w Olsztynie, 1991, 52, 129 - 136.

(10) Korboulewsky N., Dupouyet S., Bonin G.: Environmental risks of applying sewage sludge compost to vineyards: carbon, heavy metals, nitrogen, and phosphorus accumulation, J. Environ. Qual., 2002, 31, 1522 - 1527.

(11) Perucci P.: Effect of the addition of municipal solidwaste compost on microbial biomass and enzyme activities in soil, Biol. Fertil. Soils, 1990, 10, 221 - 226.

(12) Grzywnowicz I., Strutyński J.: Zmiany niektórych właściwości chemicznych gleb po zastosowaniu osadów ściekowych do celów nawozowych, Zesz. Probl. Post. Nauk Rol., 1999, 467(1), 299 - 306.

(13) Czekała J.: Wpływ osadu ściekowego na wybrane właściwości chemiczne gleby. Zesz. Probl. Post. Nauk Rol., 2004, 499, 39 - 46. 